\title{
Learning world languages
}

For most of us languages aren't all that easy to use, or learn whether we have been born into one or several languages, or have to learn one or more 'alien' languages, with alien writing systems. This may just be part of the general hurly-burly of life, and is certainly the usual way of things in, say, India, Nigeria and the Philippines, or it may happen in the comparative calm of classroom and library (nowadays widely regarded as the 'proper' way to learn languages, even if it is not always the most effective). The first of these is, as it were, the 'marketplace' tradition (learning as you go), the second the 'monastery' tradition (classrooms, timetables, exams, and accreditation).

Languages aren't easy to teach either, whatever claims may be made for particular methods, approaches, courses, and trainers. Among professional language teachers there appear to be three main approaches:

- following a method or a book step by graded step, learning, revising, moving on, chunk by sequenced chunk, with or without technological help (and often with translation)

- moving through a flexible range of materials, audio and visual, with as much 'immersion' as possible

- eclectically mixing the two (and anything else that comes to hand): a bit of real life here, a bit of formal grammar there, a list of words to learn...

Few people learn languages for the joy of it or have much freedom of choice in what they study. In this issue, Roger Wright's article on Latin and English as world languages reminds us that in Europe for many centuries Latin was the primary goal of formal language learning. For me, his discussion of 'Latin', then 'Romance', then 'the Romance languages' (but all still 'Latin') is intriguing. There are still lessons to be learned about language and language teaching by considering the nature and fate of Latin, especially in relation to 'today's Latin': the English language. My own article which follows, concerning Singapore seeking for its citizens an 'internationally acceptable English', and contemplating reintroducing the explicit teaching of grammar in order to achieve it, may show that what happened to Latin and the Romance languages might happen again, to Standard English and 'the Englishes'. Plus ça change, as they say in that other language.

Tom McArthur

The editorial policy of English Today is to provide a focus or forum for all sorts of news and opinion from around the world. The points of view of individual writers are as a consequence their own, and do not reflect the opinion of the editorial board. In addition, wherever feasible, ET generally leaves unchanged the orthography (normally British or American) and the usage of individual contributors, although the editorial style of the journal itself is that of Cambridge University Press.

(c) Cambridge University Press 2004. No contents may be reproduced by any means without the permission of Cambridge University Press.

English Today (ISSN 0266-0784) is a quarterly.

Publisher: Cambridge University Press, The Edinburgh Building, Cambridge CB2 2RU, United Kingdom. Telephone (01223) 312393 Email:

journals marketing@cup.cam.ac.uk Subscriptions: The 2004 subscription price (excluding VAT) for four issues for libraries and institutions, which includes print and electronic access, is f85.00 outside of North America; $\mathrm{f} 32.00$ for individuals; $\mathrm{f} 26$ for students and the retired. The electronic-only price available to institutional subscribers is $f 75.00$. Prices include delivery by air where appropriate. Apply to Jane Crossland at the above address.

Advertising Sales: write to the Advertising Promoter at the above address.

USA, CANADA AND MEXICO:

Publisher: Cambridge University Press, 40 West 20th Street, New York, NY 10011-4211, USA.

Telephone (212) 9243900.

Subscriptions: The 2004 subscription price (excluding VAT) for four issues for libraries and institutions, which includes print and electronic access, is $\$ 134.00$ in USA, Canada and Mexico; $\$ 50.00$ for individuals; $\$ 38$ for students and the retired. The electronic-only price available to institutional subscribers is $\$ 113.00$. Apply to Marianne Headrick at the above address.

Advertising Sales: write to the Advertising Coordinator at the above address.

Periodicals postage paid at New York, NY and at additional mailing offices. POSTMASTER: send address changes in USA, Canada and Mexico to English Today, Cambridge University Press, 110 Midland Avenue, Port Chester, New York, NY 10573-4930, USA.

Japanese prices for institutions are available from Kinokuniya Company Ltd, P.O. Box 55, Chitose, Tokyo 156, Japan.

Contacting the Editor: Email Dr Tom McArthur at <Scotsway@aol.com> or write to him at 22-23 Ventress Farm Court, Cherry Hinton Road, Cambridge CB1 8HD, UK. Tel 01223245934.

Internet access This journal is included in the Cambridge Journals Online service which can be found at http://uk.cambridge.org/journals. For further information on other Press titles access http://uk.cambridge.org.

Designed and typeset by Peter Ducker. Printed in the United Kingdom at the University Press, Cambridge. 